\title{
MOKYTOJO ASMENYBĖS BRUOŽŲ IR UGDYMO PROCESE ATLIEKAMŲ VAIDMENŲ RYŠYS SU PAAUGLIŲ ORUMO UGDYMUSI
}

\author{
Akvilè Virbalienė \\ Klaipédos kolegija, Klaipéda, Lietuva
}

\begin{abstract}
Akvilė Virbalienė. Vytauto Didžiojo universiteto socialinių mokslų edukologijos krypties doktorantė. Klaipėdos kolegijos Mokslo ir taikomųjų tyrimų skyriaus vedeja, Socialinio darbo katedros dėstytoja. Mokslinių tyrimų kryptis — dorinis ugdymas, paauglių socialumo ugdymas, konfliktų valdymas ir derybų procesas įvairioje socialinejje bei ugdymo aplinkoje.
\end{abstract}

\section{SANTRAUKA}

Šiame straipsnyje analizuojami mokytoju asmenybès bruožai ir atliekami vaidmenys ugdymo procese, pagrindžiant ju ryši su paaugliu orumo ugdymusi. Mokymo ir auklejimo procesuose svarbiausias ugdymo(si) instrumentas yra mokytojo asmenybè. Asmeninès žmogaus savybès visuomenèje yra vertinamos tos, kurios parodo orumo realizavima elgesyje ir santykiuose, $t$. y. dorovinès vertybès, kuriu pagrindu reiškiasi orumas.

Tyrimo probleminis klausimas: kokie mokytojo asmenybės bruožai ir ugdymo procese atliekami vaidmenys yra susiję su paaugliu orumo ugdymu bei ugdymusi? Probleminis klausimas neatsiejamas nuo tyrimo objekto — ryšio tarp mokytojo atliekamu vaidmenu ir paaugliu orumo ugdymosi. Todèl išsikeltu tyrimo tikslu siekiama apibūdinti bei nustatyti mokytoju asmenybès bruožus ir atliekamus vaidmenis ugdymo procese, pagrindžiant ju ryš̨̆ su paaugliu orumo ugdymusi.

Duomenu rinkimo metodas — apklausa raštu, naudojant mišraus tipo klausimynq. Klausimynq sudarè 7 matricos tipo klausimai, apimantys 63 uždarus teiginius.

Statistinè tyrimo duomenu analizė atlikta naudojant programu paketa SPSS for Windows 12.0. Aprašomosios statistikos metodais apskaičiuotos ¿̇vairiu rodikliu skaitinès charakteristikos (procentinis atsakymu i klausimus skirstinys ir standartinis nuokrypis (SN), parodantis procentinius duomenis). Koreliacinè analizè atlikta pagal Spirmena, nes klausimynas nèra traktuotinas kaip standartizuotas testas. Kokybiniai duomenys analizuoti remiantis kokybine turinio analize.

Straipsnyje atskleidžiama, kad mokytojas ugdymo procese atlieka vyresniojo draugo (mentoriaus), klasès lyderio, auklètojo, informatoriaus, dalyko dèstytojo ir socialinio pedagogo vaidmenis. Gauti kiekybinio tyrimo rezultatai leidžia teigti, kad: a) mokytojo, kaip mentoriaus, vaidmuo egzistuoja tik teoriškai, nes mokytojai menkai tegeba pelnyti moksleiviu pasitikejjimq ir mokytojas nèra tas asmuo, kuriuo pavyzdžiu jie sektu; b) mokiniai nesižavi mokytojo asmenybe ir jo buvimas klasejje nesudaro sqlygu gerai jaustis, neskatina atvirumo. Tai leidžia manyti, kad mokytojas, kaip klasès lyderis, paaugliu orumo ugdymesi neatlieka svarbaus vaidmens; c) mokytojas, kaip auklètojas, geba büti dèmesingas ir rūpestingas, tačiau mokiniai, bendraudami su auklètoju, neišmoksta gerbti savęs ir kitu; d) mokytojai retai gerbia mokiniu nuomonę ir būna teisingi, taigi mokytojas, atlikdamas informatoriaus vaidmeni, tik iš dalies turi i̇takos mokiniams ugdantis oruma; e) mokytojas, kaip dalyko déstytojas, yra plačiai išugdęs dalyko mokytojo vaidmeniui realizuoti bütinus gebejjimus; f) mokytojas, kaip socialinis pedagogas, retai geba mokinius auklèti savo asmenybès pavyzdžiu, o tai leidžia teigti, kad nedaro ’̣takos paaugliu orumo ugdymuisi.

Raktažodžiai: orumas, mokytoju vaidmenys, paaugliu orumo ugdymas.

\section{IVADAS}

$\breve{\mathrm{S}}$ iuolaikinėmis sąlygomis jaunosios kartos ugdymui didelę itaką daro masinès komunikacijos priemonès, bet reikšmingas mokytojo vaidmuo išlieka svarbus, nes mokykloje asmenybès ugdymas vyksta ne tik mokymo(si) procese, bet ir pedagogo pavyzdžiu (Rajeckas, 2004). Norint išugdyti orų žmogų, pirmiausia reikia būti pačiam tokiam ir čia svarbus pedagogo elgesio pavyzdys ir ugdytojo asmenybe kaip orumo ugdymo priemonè (Jovaiša, 2003; Bitinas, 2004; Martišauskiené, 2004; Thomas, Shannon, 2004). Paauglystès laikotarpiu jauni žmonès stebi mokytojo elgesi, vertybines nuostatas, t. y. kaip ugdytojo žodžiai ir aiškinimai sutampa su veiksmais (Prenciple, Helwing, 2002; Dževečka, 2003; Jovaiša, 2003; Grinevičienė, 2004; Martišauskienè, 2004). Jei mokytojas netenka mokinių pasitikejjimo, formuojasi ne tik nepagarbus po- 
žiūris į mokytoją, bet ir i jo dèstomą dalyką, pabrèžiamas vertybes, o tai yra didelè žala paaugliu doroviniam auklèjimui. Taigi išryškejja pedagogo auklètojo pavyzdžio reikšmė orumo ugdyme(si) ir stipreja nuostata mokytojo profesionalumą labiau sieti su moraliniu kryptingumu (Valatkienè, 2000; Aramavičiūtè, 2005). Kitaip tariant, morale neatsiejama nuo mokytojo profesionalumo, nes i mokytoją žiūrima kaip i prasmès kūrèją, o jo darbas laikomas asmenų tarpusavio veikla, kurios tikslas - daryti įtaką mokinių tapsmui žmonèmis (Lepeškiené, 1996; Rowe, 2000; Tijūnèlienè, 2002; Aramavičiūtè, 2005) ir rengti tokius žmones, kurie pakeistų dabartinę sergančią visuomenę (Tijūnèlienè, 2002). Taigi patvirtinama A. Lobato (2001) nuostata, kad šiandien reikalingi pedagogai, gebantys aprèpti visumą, suvokti gilumą, priimti tiesa, ugdyti orumą.

Lietuvoje mokytojų savybes, asmenybės bruožus, turinčius tiesioginį ryši su mokinių dvasingumo ugdymu, nagrinèjo L. Jovaiša (2003), V. Kavaliauskienė (2001), O. Tijūnèlienè (2002), E. Martišauskienè (2004), V. Aramavičiūtè (2005). V. Lepeškienè (1996) ir kt. atliko mokytoju asmenybès bei vertybių tyrimus. E. Martišauskienė (2004) tyrinèjo pedagogo asmenybès dvasinès brandos itaką paauglių dvasingumui. Tyrimų apie mokytojų asmenybės bruožuc ir vaidmenu itaką paauglių orumo ugdymuisi nėra atlikta Lietuvos ir tarptautiniu mastu. Taigi mokytojo vaidmens bruožų itaka paauglių orumo ugdymo procese išlieka aktuali ir nauja tyrimo tema bei mokslinè problema, juoba kad orumo ugdymas ir ugdymasis neturi formalios žinių sistemos, kurią gali perduoti ugdytojas ugdytiniams. Šiame kontekste iškyla toks probleminis klausimas: kokie mokytojo asmenybės bruožai ir ugdymo procese atliekami vaidmenys yra susiję su paauglių orumo ugdymu bei ugdymusi? Probleminis klausimas neatsiejamas nuo tyrimo objekto - ryšio tarp mokytojo atliekamų vaidmenų ir paauglių orumo ugdymosi. Todèl išsikeltu tyrimo tikslu siekiama apibūdinti bei nustatyti mokytojų asmenybės bruožus ir atliekamus vaidmenis ugdymo procese, pagrindžiant ju ryši su paauglių orumo ugdymusi.

\section{TEORINIS TYRIMO PAGRINDIMAS}

Edukologija orumo sąvoką apibrèžia kaip tam tikroje amžiaus pakopoje atsirandančią asmenybès nuostatą savo vertingumo visuomenèje atžvilgiu, reguliuojama pagal socialines normas ir vertybes, garbingą asmenybès elgesi (Jovaiša, 1993). Tokia nuostata igyjama amžiaus pakopoje, kai asmenybè gali įrodyti savo vertingumą. Savęs pažinimas, savivertès pajautimas ir pripažinimas yra aktualiausias paauglystejje (Nurmi, 1993; Pikūnas, Palujanskienè, 2000). Tai reiškia, kad orumas yra vidinè vertybè, daranti įtaką garbingai žmogaus elgsenai ir žmogus už tai yra vertinamas. Ši nuostata susiformuoja patyrus savo vertę ir santykiuose su kitais per bendrą veiklą (Harris, 1997). Vadinasi, paaugliai ugdosi orumą tarpusavio santykiuose ne tik su draugais, bet ir su mokytojais, nes ju sąveika vyksta bendroje veikloje.

Pasak I. Leliūgienès (2002), mokyklose skiriamas menkas dèmesys žmogaus orumą ugdančių priemonių igyvendinimui, trūksta sistemiškumo, menką dèmesi mokytojai skiria mokiniu esminiu vertybių nuostatų ugdymui ir gilinimui. Orumo ugdymas(is) prasideda nuo mokymo(si) ir auklèjimo(si) procesų vienovès bei jų suderinamumo (Weisbound, 2003). Mokymo ir auklèjimo procesuose svarbiausias ugdymo(si) instrumentas yra mokytojo asmenybe (Bulajeva, 2000; Valatkienè, 2000; Martišauskienè, 2004). Vadinasi, svarbu pripažinti mokytojo asmenybès įtaką mokinių orumo ugdymui(si). Pirmoji autoriteto igijimo sąlyga - moralinè atsakomybè už patikètą darbą, už auklètinių mokslinę, dorinę, dvasinę kultūrą (Jovaiša, 2003). Vadinasi, mokytojas tarp mokinių igyja autoritetą atlikdamas skirtingus vaidmenis ugdymo procese. Mokytojų darbe išskiriami du veiklos komponentai: mokymo procesas ir įvairi užklasinè veikla. Taigi galima teigti, kad pirmo mokytojo veiklos komponento atveju mokytojas atlieka dalyko dèstytojo, informatoriaus vaidmenis, vyresniojo draugo (mentoriaus) (Butkiené, Kepalaitè, 1996; Tumėnienè, Janiūnaitè, 2002; Rajeckas, 2004), o antro — klasès lyderio, aukletojo, socialinio pedagogo vaidmenis (Butkienè, Kepalaitè, 1996; Dapkienè, 2002; Rajeckas, 2004).

\section{TYRIMO METODIKA}

Tiriamieji. Imtis, parodanti tam tikrą generalinès aibès dali arba tiriamosios grupès dydi, pasak K. Kardelio (2002), priklauso nuo tyrimo tikslo, tiriamos populiacijos savybiu ir įvairių, dažnai nuo tyrinètojo valios nepriklausančių, atsitiktinių aplinkybių. Atsižvelgiant į tai, imties tūris turi būti pakankamas, kad tyrimo rezultatai kuo mažiau priklausytų nuo atsitiktinių veiksnių. 
Tyrimo imtis yra netikimybinè patogioji, nes respondentai parinkti taikant netikimybinès atsitiktinès grupès parinkimo būdą. Tyrimui buvo parenkami asmenys, kuriuos lengva rasti, kurie yra greta (Kardelis, 2002).

Parinkta imtis vadinta kriterijine, nes respondentai turejo atitikti tokius kriterijus: $13-16 \mathrm{~m}$. amžiaus paaugliai, besimokantys $7-9$ klasèse. Demografinès tiriamujų charakteristikos yra šios - moksleiviu pasiskirstymas: a) pagal lyti $(42,7 \%$ vaikinai ir $57,3 \%$ merginos); b) pagal amžių (28,01\% trylikamečių, 30,66\% keturiolikmečių, 38,33\% penkiolikmečiu ir 3\% šešiolikmečių; c) pagal klases (31,33\% septintoku, 35,34\% aštuntoku, 33,33\% devintokų).

Norint visavertiškiau atskleisti orumo ugdymosi tendencijas, tiriamieji atrinkti pagal skirtingus miestų demografinius bruožus, t. y. iš miestų (Klaipèdos, Šiauliu), miesteliu (Kretingos, Joniškio) ir kaimų (Pagègių, Inpilties, Gataučių, Vydmantų).

Kadangi tyrimo tikslas nèra orientuotas i lyginamają analizę ir siekiama nustatyti orumo ugdymosi bendrąsias tendencijas, tai duomenys analizuoti kaip bendra statistinė visuma, neskirstant pagal amžių ir kitus nepriklausomus kintamuosius. Tiriant vertybes, tokią taktiką pasirinkti rekomenduoja D. Polit ir B. Huigler (2004), C. Robson (2004).

Tyrimo metodai. Duomenu rinkimo metodas - apklausa raštu, naudojant mišraus tipo klausimyną. Klausimyną sudare 7 matricos tipo klausimai, apimantys 63 uždarus teiginius. Šios teiginių matricos parodo teoriškai išanalizuotus 7 mokytojų vaidmenis, ir tai užtikrina klausimyno turinio patikimumą (Wilkinson, Birmingham, 2003). Kiekviena matrica sudaryta iš skirtingo kiekio teiginių, leidžiančių identifikuoti konkretu mokytojo vaidmeni paauglių orumo ugdymesi. Kiekvienas matricos teiginys turèjo būti įvertintas viena verte, pasirenkant ją iš keturiu galimu (tikrai taip, taip, tikrai ne, ne). Du atviro tipo klausimai pateikti apie mokytojo itaką mokiniui klaseje ir mokinio nuomonès svarbą mokytojui. Atsakymų i šiuos klausimus duomenys leido papildyti kiekybinio tyrimo metu gautą informaciją. Kadangi mokytojo itaka analizuota kokybiniu metodu, tai atliekant tokio tipo duomenu analizę patikimumo statistiniai rodikliai yra neaktualūs (Robson, 2004). Ryšio tarp kintamujų reikšmingumo lygmuo tyrimo metu laikytas svarbiu, kai paklaida yra ne didesnè kaip $1 \%(\mathrm{p}<0,01)$.

Duomenų analizės metodai. Statistinè tyrimo duomenų analizè atlikta naudojant programų paketą
SPSS for Windows 12.0. Aprašomosios statistikos metodais apskaičiuotos įvairių rodiklių skaitinès charakteristikos (procentinis atsakymu i klausimus skirstinys ir standartinis nuokrypis (SN), parodantis procentinius duomenis). Koreliacinè analizè atlikta pagal Spirmena, nes klausimynas nèra traktuotinas kaip standartizuotas testas (Robson, 2004).

Kokybiniai duomenys analizuoti remiantis kokybine turinio analize. Analizès metu išskirtos kategorijos ir subkategorijos, o duomenu analizès procesas apėmè penkis žingsnius (Žydžiūnaitė, 2005): manifestinių kategorijų išskyrimas remiantis raktažodžiais; kategorijų turinio skaidymas i subkategorijas; kategorijų (subkategoriju) turinio elementu persidengimo identifikavimas; turinio duomenų interpretavimas.

\section{REZULTATAI}

Mokytojas - vyresnysis draugas. Didžiausio pritarimo sulaukẻ šie teiginiai: „Mokytojas geba bendrauti su mano amžiaus moksleiviais“ $(\mathrm{SD}=0,812)$, „Mokytojas padeda nugalèti kliūtis mokantis“ (SD = 0,863) ir "Mokytojas galètu atstovauti moksleiviu interesams“ ( $\mathrm{SD}=0,888)$. Moksleiviai pritare teiginiui „Mokytojas galètų tapti mano draugu“" $(\mathrm{SD}=0,919)$, rodančiam mokytojo gebejjimą tapti moksleivių draugu.

Neigiamai vertinami teiginiai: „Galečiau mokytoju pasitikèti kaip tikru draugu“ ( $\mathrm{SD}=0,777)$ ir „Mokytojas yra tas asmuo, kurio pavyzdžiu aš sekčiau“ ( $S D=0,681)$. Koreliacinè analizè atskleidžia moksleivio bendravimo su mokytoju poreikius, pavyzdžiui, kuo dažniau moksleivis gali kreiptis i mokytoją svarbiais klausimais, tuo didesnè tikimybė mokytojui tapti moksleivio draugu $($ rho $=+0,814 ; \mathrm{p}=0,000)$.

Pakankamai didelis ryšys sieja mokytojo gebejimą igyti mokinių pasitikèjimą, norint tapti ju draugu (rho $=+0,838 ; p=0,000$ ).

Mokytojas - klasès lyderis. Neigiami atsakymai dominuoja beveik visuose teiginiuose: „Aš žaviuosi mokytojo asmenybe“ ( $\mathrm{SD}=0,844)$, „Mokytojas man yra autoritetas“ $(\mathrm{SD}=0,755)$. Pirmieji du teiginiai rodo gebejjimą žavèti moksleivius savo asmenybe ir būti autoritetu, tačiau moksleiviai nelaiko mokytoju autoritetu. Daugiausia teigiamai atsakyta i teigini ,Mokytojas lengvai bendrauja su manimi" $(\mathrm{SD}=0,998)$. Šis teiginys rodo gebejjimą laisvai ir lengvai bendrauti su moksleiviais. Neigiami respondentu atsakymai i teiginius „Mokytojo buvimas klasèje 


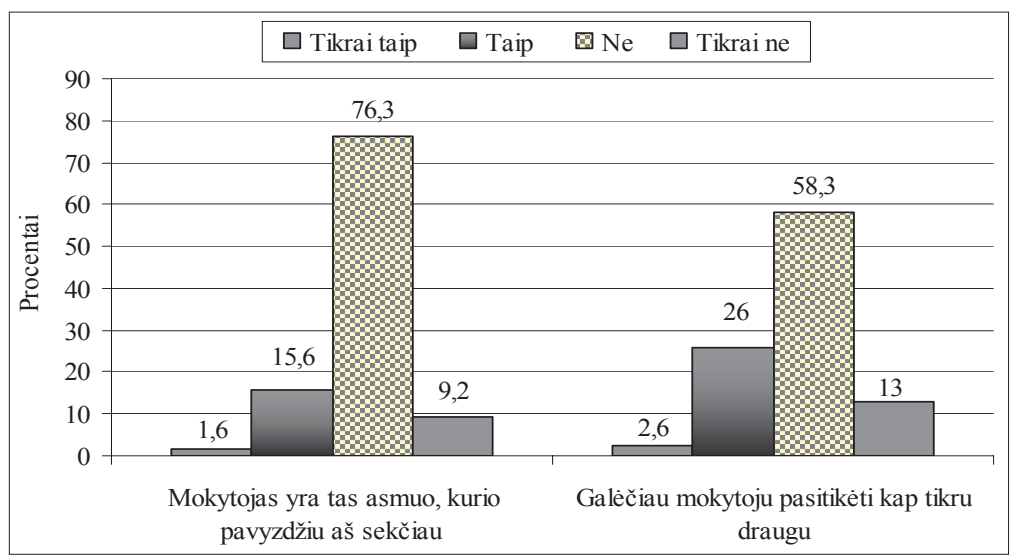

2 pav. Mokytojo gebėjimas skatinti pagarbą sau ir kitiems

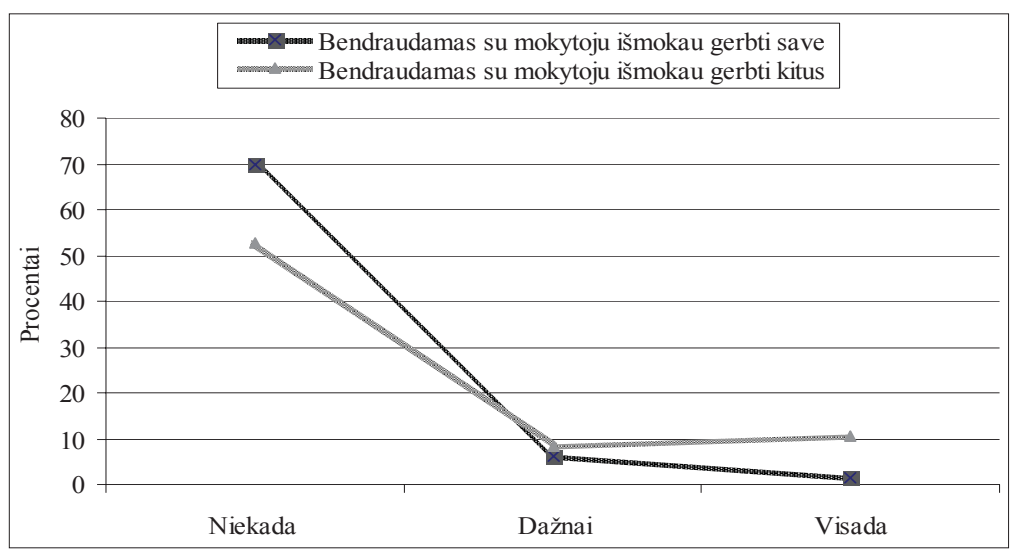

skatina mūsų, moksleivių, atvirumą، $(\mathrm{SD}=0,647)$ ir „Mokytojo buvimas klaseje sudaro sąlygas man gerai jaustis“ ( $\mathrm{SD}=0,830)$ leidžia teigti, kad retas mokytojas yra įvaldęs bendravimo su moksleiviais gebejjimą.

Koreliacinè analizè rodo, kad mokytojo gebèjimas lengvai rasti kalbą su mokinio bendraamžiais lemia mokinio norą praleisti laisvalaiki su mokytoju ne mokymosi aplinkoje (rho $=+0,784$; $\mathrm{p}=0,001)$. Mokiniai žavisi mokytojo asmenybe, kai jis yra autoritetas ( $r h o=+0,764 ; p=0,002$ ) ir kai mokiniams yra svarbi mokytojo nuomonè (rho $=+0,686 ; \mathrm{p}=0,011)$.

Mokytojas - auklètojas. Tiriamuju pritarimo sulaukè teiginys „Mokytojas nebijo parodyti, kad jam rūpi ugdytiniai“" $(\mathrm{SD}=0,102)$, kuris atskleidžia mokytojo rūpestingumą. Teigiamai įvertintas teiginys „Mokytojas bendrauja su klasès draugais neišskirdamas nei vieno" $(\mathrm{SD}=0,894)$, kuriuo nustatytas mokytojo gebejjimas būti dèmesingu. Mokytojas, realizuodamas auklètojo vaidmeni, turi rodyti pagarbą mokiniui, savo asmenybès pavyzdžiu skatinti gerbti save ir kitus. Šiam gebejimui identifikuoti buvo pateikti tokie teiginiai: „Bendraudamas su mokytoju išmokau gerbti save“ $(\mathrm{SD}=0,102)$ ir „Bendraudamas su mokytoju išmokau gerbti kitus" ( $\mathrm{SD}=0,116)$.
Dauguma mokinių šiuos teiginius ịvertino neigiamai ir tik mažiau negu 10\% mokinių teigia, kad bendraudami su mokytojais jie mokosi gerbti save ir kitus. Vadinasi, paaugliams mokytojas, kaip bendravimo partneris, nèra patikimas. Mokiniai akcentuoja, kad mokytojo dèmesingumas mokiniams lemia galimybę patikèti savo problemas mokytojui (rho $=+0,896 ; \mathrm{p}=0,013$ ). Prasmingi statistiniai ryšiai atsiskleide tarp mokytojo skatinimo prisiimti atsakomybę už savo veiksmus ir poelgius su: išmokimu gerbti kitus (rho $=0,792$; $\mathrm{p}=0,000 ; \mathrm{p} \leq 0,01)$ ir su išmokimu gerbti save (rho $=+0,841 ; p=0,000$ ).

Mokytojas - informacijos perteikèjas. Didžiausio pritarimo sulaukè teiginys, identifikuojantis būtinumą mylèti mokinius — „Mokytojas turi mylèti savo mokinius“" $(\mathrm{SD}=0,769)$. Mokiniams svarbu, kad mokytojas, perduodamas informacija, gebėtų išreikšti pedagoginę meilę. Didelio pritarimo sulauke teiginys, atskleidžiantis mokinio gebejjimą jaustis vertingu: ,Mokytojas skatina jaustis vertin$\mathrm{gu}^{\text {“ }}(\mathrm{SD}=0,838)$. Mokytojas, atlikdamas informacijos perteikejo vaidmeni, turi palengvinti mokiniu mokymosi procesą. Šiems gebejimams nustatyti buvo pateikti tokie teiginiai: „Mokytojas pamokos metu gerbia mano nuomonę" $(\mathrm{SD}=0,756)$ ir „Mokytojas pamokos metu stengiasi būti teisingas“ 


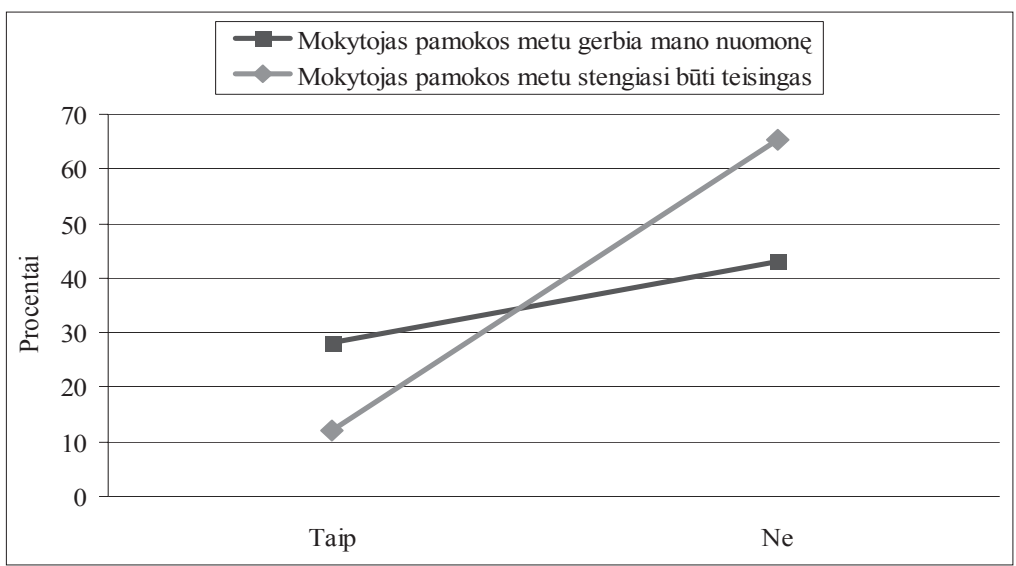

3 pav. Mokytojo gebėjimas būti teisingu ir reikšti pagarbą mokinių nuomonei

$(\mathrm{SD}=0,921)$. Šių teiginių neigiami ịverčiai leidžia daryti prielaida, kad ne visi mokytojai gerbia mokinių nuomonę ir yra teisingi pamokoje.

Koreliacinè analizè atskleide, kad mokytojas skatina paauglius jaustis vertingais, kai pamokos metu gerbia moksleivių nuomonę ( $r$ ho $=+0,869$; $\mathrm{p}=0,000)$ ir kai stengiasi būti teisingas $(\mathrm{rho}=+0,842 ; \mathrm{p}=0,005)$. Prasmingas statistinis ryšys atsiskleidè tarp mokytojo dalykiškumo pamokos metu ir jautrumo mokinių nesėkmèms $($ rho $=+0,843 ; \mathrm{p}=0,143)$.

Mokytojas - dalyko dèstytojas. Mokiniu pritarimo sulaukè teiginiai: „Kai mokytojas yra klasèje, mūsų nereikia drausminti“" $(\mathrm{SD}=0,709)$, "Mokytojas skatina visus moksleivius pasisakyti“" $(\mathrm{SD}=0,773)$, kurie rodo mokytojo gebejjimą palaikyti tvarką klasejje ir skatinti mokinius būti aktyviais pamokoje. Teiginiais „Mokytojas išklauso mano nuomonę, jei jis ir nesutinka su ja“" $(\mathrm{SD}=0,675)$ ir „Mokytojas niekuomet neišjuokia mūsu pasirinkimu“" $(\mathrm{SD}=0,975)$ buvo nustatytas gebejimas išklausyti ugdytinių nuomonę ir ją gerbti.

Statistiškai reikšminga koreliacija tarp mokytojo skatinimo pasisakyti ir mokinio nuomonès išklausymo, nors ir nesutinka su ja (rho $=+0,676$; $\mathrm{p}=0,017)$, parodo dalyko mokytojo gebejjimą gerbti ir išklausyti mokinių nuomonę.

Mokytojas - socialinis pedagogas. Neigiamai vertinami teiginiai: „Mokytojas auklèja mane savo pavyzdžiu“ ( $S D=1,184)$. Teigini „Mokytojas yra draugiškas, todèl lengva su juo bendrauti“" $(\mathrm{SD}=2,196)$ mokiniai ivertino adekvačiai - teigiamai $50 \%$ ir neigiamai $50 \%$. Teiginiais „Diskutuojant svarbiomis temomis, mokytojas padeda suvokti atsakomybę už savo poelgius" $(\mathrm{SD}=1,83)$ ir „Mokytojas man padeda formuotis atsakingumą" $(\mathrm{SD}=1,05)$ siekta nustatyti, ar mokytojai geba padèti moksleiviams suvokti atsakomybę už savo poelgius. $70 \%$ moksleivių pritarè šiems teiginiams. Mokiniai akcentuoja sąsajas tarp mokytojo gebejjimo užjausti mokini, kai jam sunku, ir gebejjimo išlaikyti paslaptyje mokinio ir mokytojo pokalbi (rho $=+0,693 ; \mathrm{p}=0,113)$. Mokiniai formuojasi atsakinguma, kai mokytojas su jais diskutuoja svarbiomis mokiniams temomis ir padeda suvokti atsakomybę už savo poelgius (rho $=+0,707 ; \mathrm{p}=0,000)$.

Mokytojo asmenybės bruožu kokybinis tyrimas leido atskleisti mokinių lūkesčius orumo ugdymosi atžvilgiu. Buvo pateikti šie klausimai: Kokiq itaka Tau daro mokytojas klasejje? Kokios savybès svarbios mokytojui, kad galètum pasitikèti juo kaip draugu?

Mokytojo itaka mokiniui klasėje. Mokiniai nurode 21 asmenybès bruožą, kurie atskleidžia teigiamą, neigiamą ir neutralią mokytojo įtaką.

Teigiamos ittakos kategorijoje išskirta penkiolika subkategorijų, kurios atskleidžia mokytojo teigiamą itaką klaseje mokiniams ugdantis orumą, pvz: draugiškumas, mokytojo asmenybè, atsakomybès ugdymas, tarpusavio ryšys, gebejimas paskatinti.

Neigiamos ittakos kategorijoje išskirtos trys subkategorijos: mokytojo neprofesionalumas (,veidmainis“, „negerbia mano nuomonès“, ,jis mane nervina, nes nusišneka"); neigiama nuostata i mokytoją (,jis neteisingai vertina“"); nepaaiškinta neapykanta mokytojui (,kai kurie mokytojai nervina, o su kai kuriais bjauru net bendrauti“). Pastarosios atskleidžia mokytojų neprofesionalumą, pedagoginio pašaukimo ir kompetencijos stoką dirbant pedagogini darbą.

Neutralios itakos kategorijoje išskirtos dvis subkategorijos: itakos nebuvimas (,,mokytojas nedaro jokios itakos, nes jo dèstomas dalykas nuobodus") ir formalus pareigos atlikimas $(, \ldots$ atlieka savo pareiga, už kurią gauna pinigus"). Šios kategorijos turinys atskleidžia, kad mokytojas, formaliai atlikdamas savo pareigas, nesudomina mokinių nei 
dèstomu dalyku, nei savo asmenybės pavyzdžiu, todèl tokio mokytojo itaka yra neutrali.

Mokytojo savybès, lemiančios mokinio pasitikèjimą. Iš pateiktų mokinių atsakymų išskirtos dvi kokybinès kategorijos: bendravimo savybe ir išoriniai bruožai. Mokiniai pateikia 17 mokytojui būtinų asmeninių savybių, iš kurių dauguma yra orientuotos $i$ charakterio savybes ir vertybes.

Kategorijoje „Bendravimo savybe“" išskirtos keturios subkategorijos (komunikabilumas, tolerantiškumas, nuomonès neprimetimas, gebejjimas išklausyti), orientuotos i socialinès kompetencijos turini, t. y. atskleisti gebejimą bendrauti ir priimti kitą žmogú.

Kategorijoje „Išoriniai bruožai“ išskirtos trys kategorijos (jaunatviškumas, simpatiškumas, graži, patraukli išvaizda). Mokiniams svarbu mokytojo išoriniai bruožai, lemiantys draugo patrauklumą, ir renkantis draugus išvaizda jiems yra pirminis veiksnys, lemiantis draugystę.

\section{REZULTATŲ APTARIMAS}

Vyresniojo draugo (mentoriaus) vaidmuo. Dalykinių santykių sistemoje paauglys gali patenkinti emocinius poreikius, kai pedagogas atlieka mentoriaus vaidmeni, bendrauja su paaugliais, rodo dèmesingumą, pasitikèjimą, pagalbą, pagarbą, atlaidumą (Bakutyte, 2001) ir taip daro itaka paauglių orumo ugdymuisi. Tačiau kiekybinio tyrimo duomenys rodo priešingą tendenciją: mokytojo mentoriaus vaidmuo egzistuoja tik teoriškai, nes mokytojai menkai tegeba pelnyti moksleiviu pasitikejjimą ir mokytojas nèra tas asmuo, kurio pavyzdžiu jie sektų. Tai leidžia daryti prielaidą, kad paaugliams ugdantis orumą, šis mokytojo vaidmuo nereikšmingas.

Klasės lyderio vaidmuo. Mokslinėje literatūroje atskleista, kad mokytojas, kaip klasès lyderis, svarbus ugdantis orumą, nes jis padeda klasès nariams harmoningai sąveikauti, bendradarbiauti, siekti bendro rezultato remiantis tarpdalykinais santykiais, pagarbos asmeniui ir darbui principais, vertybėmis, tačiau tyrimų rezultatai leidžia teigti, kad mokiniai nesižavi mokytojo asmenybe ir jo buvimas klasejje nesudaro sąlygų gerai jaustis, neskatina atvirumo. Tai leidžia manyti, kad mokytojas, kaip klasès lyderis, paauglių orumo ugdymesi neatlieka svarbaus vaidmens.

Auklètojo vaidmuo. Auklètojo vaidmuo ugdymo procese yra reikšmingas, skatinantis ugdytinị eiti savęs link: analizuoti savo pasiekimus, jausmus, vertybes, pažinimą, kurie skatintų atrasti prasmę ir savo vertingumą (Martišauskienè, 2004). Tyrimo rezultatai atskleidè, kad mokytojas, kaip auklètojas, geba būti dèmesingas ir rūpestingas, tačiau mokiniai, bendraudami su auklètoju, neišmoksta gerbti savęs ir kitu, o pagarbos sau ir kitam ugdymas yra esmine mokytojo auklètojo funkcija ugdant paauglių orumą. Vadinasi, šis vaidmuo neturi itakos orumo ugdymesi.

Informatoriaus vaidmuo. Informacijos perteikejjo vaidmuo orientuoja pedagogą i mokymą, t. y. kaip ir kur surasti tinkamą informaciją bei Ł̇vairiomis situacijomis ją pritaikyti (Tumėniené, Janiūnaite, 2002), kartu palengvinti ir mokymosi procesą. Tyrimo duomenys patvirtino, kad mokytojai geba palengvinti mokymosi procesa, vadinasi, daugeli gebėjimų, reikalingu šiam vaidmeniui realizuoti, mokytojai yra įvaldę. Tyrimo rezultatai parode, kad mokytojai retai gerbia mokiniu nuomonę ir būna teisingi, taigi mokytojas, atlikdamas informatoriaus vaidmenị, tik iš dalies turi įtakos mokiniams ugdantis oruma.

Dalyko dèstytojo vaidmuo. Mokytojas, kaip dalyko destytojas, mokymo metu sudaro kritinio mąstymo sąlygas, ir tai padeda asmeniui suvokti mokomojo dalyko esmę ir prasmę, o pasiekti rezultatai suteikia orumo jausmą (Wainryb et al., 2001). Mokymo proceso centre yra mokinio asmenybe, pagarba jam, ir tai yra viena iš pagrindinių orumo ugdymo(si) nuostatų. Tai patvirtino ir atlikto tyrimo rezultatai: mokytojas, kaip dalyko dèstytojas, yra plačiai išugdęs dalyko mokytojo vaidmeniui realizuoti būtinus gebėjimus. Pavyzdžiui, mokytojas geba gerbti ir įsiklausyti i mokinių nuomonę, skirtingai nei atlikdamas informatoriaus vaidmeni. Galima daryti prielaidą: mokiniai ugdosi orumą bendraudami su mokytoju, ir tai patvirtina nuostata, kad orumo ugdymasis vyksta dalykinių santykių sistemoje.

Socialinio pedagogo vaidmuo. Realizuodamas ši vaidmeni, mokytojas turi padèti moksleiviams suvokti atsakomybę už savo poelgius, nes orumas padeda žmogui įsisąmoninti savo pareigą ir atsakomybę visuomenei (Dapkienè, 2002). Tyrimo rezultatai patvirtino, kad mokytojai, atlikdami socialinio pedagogo vaidmeni, padeda ugdytis oruma, nes pedagoginis poveikis padeda isisąmoninti pareigos ir atsakomybès jausmą. Tyrimo rezultatai atskleidè: mokytojas, kaip socialinis pedagogas, retai geba mokinius auklèti savo asmenybės pavyzdžiu, ir tai leidžia teigti, kad nedaro itakos paaugliu orumo ugdymuisi. 
Mokymo ir auklejimo procesuose svarbiausias ugdymo(si) instrumentas yra mokytojo asmenybė (Martišauskienè, 2004). Tai geriausiai parodo kokybinio tyrimo kategorija - mokytojo teigiama itaka klasejje. Šios kategorijos turinys leidžia teigti, kad mokytojas daro teigiamą poveikị savo asmenybe, meistriškai atlikdamas mokytojo vaidmeni, kai geba realizuoti socialinę kompetenciją ugdymo procese.

Asmeninès žmogaus savybès visuomenèje yra vertinamos tos, kurios leidžia realizuoti oruma elgesyje ir santykiuose, t. y. dorovinès vertybès, kurių pagrindu reiškiasi orumas. Kokybinio tyrimo rezultatai patvirtino, kad mokiniai renkasi draugus, kurie yra tvirto charakterio ir geba bendrauti, t. y. santykiuose su žmonėmis vadovaujasi bendražmogiškomis vertybėmis. Tyrimas atskleidè, kad mokytojas, norintis tapti mokiniu draugu, taip pat yra vertinamas, pavyzdžiui, kiek jo elgesyje ir santykiuose su mokiniais reiškiasi bendražmogiškosios vertybès, kurios turi didelès itakos paaugliams ugdantis orumą.

\section{IŠVADOS}

Kiekybinio tyrimo rezultatai atskleide, kad mokytojai daro itaką mokiniams ugdantis orumą, kai: a) atlieka dalyko dèstytojo vaidmeni - išklauso mokinio nuomonę, skatina aktyviai dalyvauti pa- mokoje, niekada neišjuokia pasirinkimų, t. y. mokytojas leidžia pamokos metu mokiniui jausti savo vertę ir reikšmę; b) realizuoja socialinio pedagogo vaidmeni, pavyzdžiui, užjaučia mokini sunkioje situacijoje, garantuoja pokalbio konfidencialumą ir padeda suvokti atsakomybę už savo poelgius, ir tai leidžia mokiniui pajusti savo orumą.

Tik iš dalies daro itaką paauglių orumo ugdymuisi mokytojo atliekamas auklètojo vaidmuo. Pastarasis pasireiškia dèmesingumu ir rūpestingumu mokiniui, skatinimu prisiimti atsakomybę už savo poelgius. Mokytojai netraktuojami kaip asmenybės, kurios skatina paauglius gerbti vieniems kitus ir save.

Mokytojai atlieka informatoriaus vaidmeni, kuris atskleidžia profesionaliai perteikiant dalyko medžiagą, tačiau mokytojams, kaip informatoriams, trūksta gebejjimų gerbti mokinių nuomonę ir būti teisingiems.

Paaugliams ugdantis orumą neturi itakos mokytojo realizuojamas vyresniojo draugo vaidmuo, nes mokiniai nepasitiki mokytoju kaip tikru draugu.

Klasès lyderio vaidmeni mokytojams trukdo atlikti šiu gebejimų stoka: sudaryti sąlygas gerai jaustis klaseje, tapti autoritetu tarp mokinių. Tačiau kokybinio tyrimo duomenys atskleide, kad mokytojas daro teigiamą itaką klaseje, kai yra savo dalyko meistras ir turi socialinès kompetencijos.

\section{LITERATŪRA}

Aramavičiūtè, V. (2005). Auklëjimas ir dvasine asmenybès branda. Vilnius: Gimtasis žodis.

Bakutytè, R. (2001). Pradiniu klasiu mokiniu humaniškumo ugdymas. Šiauliai: ŠU leidykla.

Bitinas, B. (2004). Hodegetika. Vilnius: Kronta.

Bulajeva, T. (2000). Pedagogu profesinis tobulejimas ir saviugda. Acta Paedagogica Vilnensia, 7, 234-242.

Butkienè, G., Kepalaite, A. (1996). Mokymasis ir asmenybès brendimas. Vilnius: Margi raštai.

Dapkienè, S. (2002). Klasès auklètojas ir tèvai - partneriai. Radviliškis: Litera.

Dževečka, A. (2003). Lietuvos pedagogų vertybių hierarchijos problema. Pedagogika, 67, 7-11.

Grinevičienè, V. (2004). Mokytojo kompetencijos: i pedagogo asmenybę orientuoti moksleivių lūkesčiai. Pedagogika, 71, 51-55.

Harris, G. W. (1997). Dignity and Vulnerability: Strength and Quality of Character. Berkeley: University of California Press.

Jovaiša, L. (2003). Hodegetika: auklejjimo mokslas. Vilnius: Agora.

Jovaiša, L. (1993). Pedagogikos terminai. Kaunas: Šviesa.

Kardelis, K. (2002). Moksliniu tyrimu metodologija ir metodai. Kaunas: Judex.
Kavaliauskienè, V. (2001). Pedagoginis pašaukimas ir jo ugdymas. Klaipèda: KU leidykla.

Leliūgienè, I. (2002). Socialinè pedagogika. Kaunas: Technologija.

Lepeškienè, V. (1996). Humanistinis ugdymas mokykloje. Vilnius: Valstybinis leidyklos centras.

Lobato, A. (2001). Žmogaus orumas ir likimas. Vilnius: LOGOS leidykla.

Martišauskienè, E. (2004). Paaugliu dvasingumas kaip pedagoginis reiškinys. Vilnius: VPU leidykla.

Nurmi, J. E. (1993). Adolescent development in an agegraded context: The role of personal beliefs, goals, and strategies in tackling developmental tasks and standards. International Journal of Behavioral Development, 16, 169-189.

Pikūnas, J., Palujanskienė, A. (2000). Asmenybès vystymasis. Kaunas: VDU leidykla.

Polit, D., Huigler, B. (2004). Nursing Research: Principles and Methods. Philadelphia: J. B. Lippincott Company.

Prenciple, A., Helwing, C. (2002). The development of reasoning about the teaching of values in school and family contexts. Child Development, 73, 841-856.

Rajeckas, V. (2004). Pedagogikos pagrindai. Vilnius: Parama. 
Robson, C. (2004). Real World Research. Blackwell Publishing.

Rowe, D. (2000). Value pluralism, democracy and education for citizenship. Education, Culture and Values, 6, 194-203.

Thomas, A., Shannon, A. (2004). Grounding human dignity. The Journal of Moral Education, 43 (2), 113-128.

Tijūnèlienè, O. (2002). Mokytojo autoriteto samprata Lietuvoje (1918-1940). Klaipeda: KU leidykla.

Tumėnienė, V., Janiūnaitė, B. (2002). Pedagogo novacinès veiklos sampratos erdvè ir struktūra: teoriniai aspektai. Socialiniai mokslai, 1 (33), 62-76.

Valatkienè, S. (2000). Pedagogo jèga — žmoniškumas.
Acta Paedagogica Vilnensia, 7, 229-234.

Wainryb, C., Shaw, L., Smith, K. (2001). Children's, adolescents' and young adults' thinking about different types of disagreements. Developmental Psychology, 37, $373-386$.

Weisbound, R. (2003). Moral teachers, moral students. Educational Leadership, 60 (2), 24-30.

Wilkinson, D., Birmingham, P. (2003). Using Research Instruments. A Guide for Researchers. London and New York. Routledge Falmer: Taylor and Francis Group.

Žydžiūnaitè, V. (2005). Komandinio darbo kompetencijos ir ju tyrimo metodologija. Kaunas: Judex. P. 160-161.

\title{
RELATIONSHIP BETWEEN TEACHER'S PERSONAL FEATURES, ROLES IN EDUCATIONAL PROCESS AND DIGNITY DEVELOPMENT AMONG TEENAGERS
}

\author{
Akvilè Virbalienè \\ Klaipèda College, Klaipéda, Lithuania
}

\begin{abstract}
In this article the features of teacher's personality and their roles in the educational process are analyzed emphasizing their relationship with the development of dignity among teenagers. The most important educating tool in the process of teaching and training is the personality of the teacher. In the society those human peculiarities are valued which reflect the realization of dignity in behaviour and in relationships, in other words, which reflect the moral value by which the dignity is expressed.

Research problem involves of the following question: What personal features of teachers and what roles of teachers in the educational process influence teenager's dignity development.

Research focus is the relationship between teacher's roles in the educational process and the development of dignity among teenagers.

Research aim is to describe and estimate teacher's personal features and their roles that influence the dignity development among teenagers.

Methods of data collection: questionnaire survey using the mixed type questionnaire (with the open- and closed-ended questions); methods of data analysis: a) quantitative - statistical methods (using the SPSS 12.0 for Windows) to calculate frequencies, standard deviations, percentage and correlations (Spearman); b) qualitative - qualitative content analysis.

The article emphasizes the fact that in educational process teachers play the roles of senior friends (mentors), leaders of the class, educators, informers, lecturers and social pedagogues. Our results emphasized that: a) the role of the teacher as a mentor exits only in theory because teachers are not able to earn the trust of the pupils and pupils would not follow their example; b) pupils do not admire the personality of the teacher and his or her presence in the classroom does not enable open and honest communication and pupils do not feel confortable. This leads to the presumption that the teacher as a leader of the class in educating the dignity of adolescents does not play an important role; c) the teacher as an educator is attentive and careful but the pupils communicating with the educator do not learn to respect themselves and others; d) teachers seldom respect the opinion of the pupils and behave fair, therefore, the teacher as an informer can partly influence pupils in the development of their dignity; e) the teacher as a lecturer has well developed capabilities for teaching his / her subject; f) the teacher as a social pedagogue is seldom capable of educating the pupils by his / her own example and this role does not make any influence on the education of dignity among adolescents.
\end{abstract}

Keywords: human dignity, teachers' roles, dignity development among teenagers.

Gauta 2006 m. gegužès 15 d.

Received on May 15, 2006

Priimta 2006 m. gruodžio 6 d.

Accepted on December 6, 2006
Akvilè Virbalienè

Klaipèdos kolegija (Klaipèda College)

Donelaičio g. 8, LT-92143 Klaipèda

Lietuva (Lithuania)

Tel +370 46410173

E-mail akvile.virbaliene@gmail.com 